\title{
Integrated Nutrient Management for Enhancing the Soil Health, Yield and Quality of Little Millet (Panicum sumatrense)
}

\author{
Y. Sandhya Rani*, U. Triveni and T. S. S. K. Patro
}

A.N.G.R Agricultural University, Agricultural Research Station, Vizianagaram A.P. (535 001), India

\section{Corresponding Author}

Y. Sandhya Rani

e-mail: sandhya_rani337@yahoo.com

\author{
Article History \\ Manuscript No. AR1672 \\ Received in $10^{\text {th }}$ Sep, 2016 \\ Received in revised form $27^{\text {th }}$ Dec, 2016 \\ Accepted in final form $6^{\text {th }}$ Feb, 2017
}

\begin{abstract}
Integrated nutrient management is an approach for management of plant nutrients for maintaining and enhancing soil health, where both natural and man made sources of plant nutrients are used.A field experiment was conducted in little millet during Kharif 2015 at Agricultural Research Station, Vizianagaram, laid out in split plot design to evaluate the effect of integrated use of three types of organic manures in combination with three levels of inorganic fertilizers (NPK) with two varieties (Peddasamaand OLM 203) as main plots and 11 combinations of organic and inorganic fertilizers as sub plots. The grain and straw yields in little millet of both the varieties were significantly influenced by different fertilizer levels. The experimental results indicated that significantly highest grain and straw yields were recorded in the treatment 100\% RDF+Neem cake @ $1 \mathrm{t} \mathrm{ha}^{-1}$. However it was on par with 75\% RDF+Neem cake@ $1 \mathrm{t} \mathrm{ha}{ }^{-1}+$ Azospirillum @ 5 kg ha-1 $+P S B$ @5 kg ha-1, 100\% RDF+Vermicompost @ $2 \mathrm{t} \mathrm{ha}^{-1}, 75$ \% RDF+Vermicompost @ $2 \mathrm{t} \mathrm{ha}{ }^{-1}+$ Azospirillum @ 5 kg ha ${ }^{-1}+P S B @ 5$ kg ha-1 and $100 \%$ RDF+FYM @ $5 \mathrm{t} \mathrm{ha}^{-1}+$ Azospirillum @ 5 kg ha-1+PSB @ $5 \mathrm{~kg} \mathrm{ha}^{-1}$. While, maximum yields were observed with the OLM 203 variety of little millet. Moreover the uptake of macronutrients (NPK) was found to be the highest in the treatment $100 \%$ RDF+Neem cake @ $1 \mathrm{t} \mathrm{ha}{ }^{-1}$ and micronutrients ( $\mathrm{n}$ and Fe) in the treatment 100\% RDF+Vermicompost @ $2 \mathrm{t} \mathrm{ha}^{-1}$. But the benefit cost ratio was found highest in 100\% RDF treated plots followed by 100\% RDF+FYM @ $5 \mathrm{t} \mathrm{ha}^{-1}$
\end{abstract}

Keywords: Little millet, organic, inorganic, biofertilizers

\section{Introduction}

Millets are a group of highly variable small seeded grasses, widely grown around the world as cereal grains. Millets are tiny in size and round in shape and can be white, grey, yellow to red hardy and grow well in dry zones as rain-fed crops, under marginal conditions of soil fertility and moisture. Minor millets are claimed to be the future foods for better health and nutritional security. Small millets are highly nutritious superior to rice and wheat in terms of proteins, minerals, vitamins, calcium and iron content. Small millets comprising finger millet, foxtail millet, barnyard millet, little millet, proso millet and kodo millet are considered to be soothing least allergic and most digestive grains available. Among all the small millets, little millet commonly called as Sama is a reliable catch crop in view of its earliness and resistance to adverse agroclimatic conditions of high drought as well as waterlogging. Further millets are non glutinous and non acid forming foods. In order to increase the crop productivity, nutrient management may be achieved by the integration of organic sources, biofertilizers and micronutrients.

Now a days, use of chemical fertilizer is increasing to boost up the crop production which is injurious to the soil health and soil productivity and also increases the cost of cultivation. On account of continuing world energy crises and spriling price of chemical fertilizer, the use of organic manure as a renewable source of plant nutrients is gaining importance. In this endeavour proper blend of organic and inorganic fertilizer is important not only for increasing yield but also for sustaining soil health (Weber et al., 2007; Larney and Hao, 2007; Pullicinoa et al., 2009). The long term use of inorganic fertilizers without organic supplements damages the soil physical, chemical and biological properties and causes environmental pollution (Zhong and Cai, 2007). Organic manures act not only as a source of nutrients but also increase the bio-diversity and activity of the microbial population in soil. Compost amendments enhance SOM quality and quantity by an increased accumulation of various classes of organic compounds. Enhanced SOM mainly focus on changes of bulk organic carbon (Pedra et al., 2007; Sebastia et al., 2007) microbial biomass, macro and micronutrients availability (Kowaljow and Mazzarino, 2007) and organic matter pools such as Dissolved Organic Matter (DOM) and humic substances (Adani et al., 2007). The integrated use of organic materials 
and inorganic nitrogenous fertilizers has received considerable attention in the past with the hope of meeting the farmers economic need as well as maintaining favourable ecological conditions on long-term basis (Kumar et al., 2007).

Further integrated nutrient management influences the structure, nutrients turn over and many related physical, chemical and biological parameters of the soil. Integration of inorganic, organic and bio-fertilizers play a vital role for enhancing crop productivity and sustaining soil fertility, which proves a great promise to the farmers. Integrated nutrient supply involving conjunctive use of fertilizers and organic sources of nutrients assumes a greater significance. Farmyard manure improves the physical condition of soil by increasing water holding capacity for maximum utilization of water (Hati et al., 2006). It also improves the chemical and biological condition of soil by increasing cation exchange capacity and providing various vitamins, hormones and organic acids which are very important for soil aggregation and for beneficial micro-organisms which are involved in various biochemical processes and release of nutrients. The recovery of nitrogenous fertilizers is generally low for most crops especially in Indian soils because of faster nitrification and voltalization, which can be minimized by use of organic sources as they act as nitrification inhibitors.

Increased levels of production can be achieved by increased use of inorganic fertilizers, but may lead to deterioration in soil quality besides pollution problems (Schulz and Glaser, 2012). Maintaining and improving soil quality is thus crucial if agricultural productivity and environmental quality are to be sustained for future generations (Reeves, 1997). Hence the present experiment was undertaken to study the effect of organic manures and biofertilizers in combination with inorganic fertilizers on growth and yield of two varieties of little millet.

\section{Materials and Methods}

The field experiment was conducted during Kharif, 2015 at Agricultural Research Station, Vizianagaram. The soil was sandy loam in texture, low in Organic Carbon, available Nitrogen, high in available Phosphorus and medium in available Potassium. The experiment was laid down in split plot design with two main plots and eleven sub plots replicated thrice. The treatments were $\mathrm{T}_{1}: 0 \% \mathrm{RDF}$ (control); $\mathrm{T}_{2}: 100 \%$ RDF+FYM @ $5 \mathrm{t} \mathrm{ha}^{-1} ; \mathrm{T}_{3}: 75 \% \mathrm{RDF}+\mathrm{FYM} @ 5 \mathrm{tha}$ ${ }^{1}+$ Azospirillum @ $5 \mathrm{~kg} \mathrm{ha}^{-1}+P S B @ 5 \mathrm{~kg} \mathrm{ha}^{-1} ; \mathrm{T}_{4}: 50 \% \mathrm{RDF}+\mathrm{FYM}$ @ 5 t ha-1 + Azospirillum @ $5 \mathrm{~kg} \mathrm{ha}^{-1}+P S B @ 5 \mathrm{~kg} \mathrm{ha}^{-1} ; \mathrm{T}_{5}: 100 \%$ RDF+Vermicompost @ $2 \mathrm{t} \mathrm{ha}^{-1}$; $\mathrm{T}_{6}: 75 \% \mathrm{RDF}+$ Vermicompost @ 2 t ha- ${ }^{-1}$ Azospirillum $5 \mathrm{~kg} \mathrm{ha}^{-1}+P S B @ 5 \mathrm{~kg} \mathrm{ha}{ }^{-1} ; \mathrm{T}_{7}: 50 \%$ RDF+Vermicompost @ 2 t ha ${ }^{-1}+$ Azospirillum 5 kg ha ${ }^{-1}+P S B$

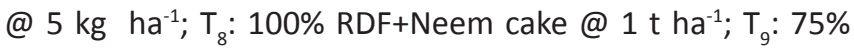
RDF+Neem cake @ $1 \mathrm{tha}^{-1}+$ Azospirillum @ $5 \mathrm{~kg} \mathrm{ha}^{-1}+P S B @ 5$

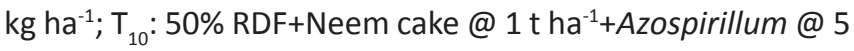
kg ha-1 $+P S B @ 5 \mathrm{~kg} \mathrm{ha}^{-1} ; \mathrm{T}_{11}: 100 \% \operatorname{RDF}(20-20-20$ NPK kg ha-1)
Two locally popular varieties of little millet (Peddasama and OLM, 203) were taken as main plots with eleven subplots consisting of 3 levels of fertilizers (100\% RDF, 75\% RDF and $50 \%$ RDF) in combination with 3 types of organic manures FYM @ 5 t ha- ${ }^{-1}$, Vermicompost @ 2 t ha ${ }^{-1}$ and Neem cake @ $1 \mathrm{t} \mathrm{ha}^{-1}$ and two types of Biofertilizers (Azospirillum and PSB). Uniform cultural practices were carried out in all the experimental plots of $3 \times 3 \mathrm{~m}^{2}$ and healthy seeds of both the varieties were sown with a spacing of $30 \times 10 \mathrm{~cm}^{2}$ in all the plots. Required population was maintained by thinning and gap filling whenever required.

All the three levels of inorganic fertilizers were applied in the form of urea, DAP and MOP combined with organic manures (FYM, Vermicompost and Neem cake) and biofertilizers (Azospirillum @ 5 kg ha-1 and PSB @ 5 kg ha-1) were applied as basal dose. The crop was maintained under uniform conditions of weeding, irrigation and need based plant protection measures.

Growth parameters viz., plant height, No. of productive tillers, leaf length, leaf width, inflorescence length, No. of spikes plant $^{-1}$, straw and grain yield were recorded at the time of harvest. The initial soil samples before sowing of the crop and final soil samples after harvest of the crop was analysed for $\mathrm{pH}, \mathrm{EC}$, available $\mathrm{N}, \mathrm{P}_{2} \mathrm{O}_{5}, \mathrm{~K}_{2} \mathrm{O}$ and available micronutrients viz., $\mathrm{Zn}, \mathrm{Fe}, \mathrm{Cu}$ and $\mathrm{Mn}$ as per the procedures. The plant samples of both the grain and straw of both the varieties of little millet were prepared and analysed for both macro and micronutrient uptake.

\section{Results and Discussion}

The growth characters such as plant height and leaf length weresignificantly influenced with the application of different types of organic manures in conjunction with inorganic fertilizers and found highest in the treatment $100 \%$ RDF+Neem cake @ 1 t ha $^{-1}$ (Table 1). The yield contributing characters viz., No. of productive tillers, Inflorescence length and No. of spikes plant $^{-1}$ were found highest in the treatment $100 \%$ RDF+Neem cake@1 t ha-1 and found on par with the treatment of 100\% RDF+FYM @ 5 t ha $^{-1}$ and 100\% RDF+Vermicompost @ 2 t ha-1, 75\% RDF+Vermicompost @ 2 t ha ${ }^{-1}+$ Azospirillum 5 kg ha-1+PSB @ $5 \mathrm{~kg} \mathrm{ha}^{-1}$ and 75\% RDF+Neem cake @ $1 \mathrm{t}$ ha-1 + Azospirillum 5 kg ha-1 + PSB @ 5 kg ha ${ }^{-1}$ (Table 1). The enhancement in tiller no. and plant height is attributed to rapid conversion of synthesized carbohydrates into protein and consequent increase in the no. and size of growing cells, resulting ultimately in increased no. of tillers (Zeidan, 2007).

Significantly higher grain and straw yields were recorded with the treatment 100\% RDF+Neem cake @ 1 t ha-1, which is on par with 75\% RDF+Neem cake @ 1 t ha-1 + Azospirillum $5 \mathrm{~kg} \mathrm{ha}^{-1}+P S B @ 5 \mathrm{~kg} \mathrm{ha}{ }^{-1}, 100 \% \mathrm{RDF}+$ Vermicompost @ $2 \mathrm{t}$ ha-1, 75\% RDF+Vermicompost @ 2 t ha-1 + Azospirillum 5 kg ha ${ }^{-1}+P S B @ 5$ kg ha ${ }^{-1}, 100 \%$ RDF+FYM @ 5 t ha-1 compared to the treatment in which only inorganic fertilizers were used and 


\begin{tabular}{|c|c|c|c|c|c|c|c|c|}
\hline & $\begin{array}{c}\text { Plant } \\
\text { height }(\mathrm{cm})\end{array}$ & $\begin{array}{l}\text { Productive } \\
\text { tillers plant }{ }^{-1}\end{array}$ & $\begin{array}{l}\text { Leaf length } \\
(\mathrm{cm})\end{array}$ & $\begin{array}{c}\text { Leaf } \\
\text { width }(\mathrm{cm})\end{array}$ & $\begin{array}{l}\text { Infloresence } \\
\text { length }(\mathrm{cm})\end{array}$ & $\begin{array}{l}\text { No. of spikes } \\
\text { Panicle }^{-1}\end{array}$ & $\begin{array}{l}\text { Straw wt } \\
\left(q \text { ha }^{-1}\right)\end{array}$ & $\begin{array}{c}\text { Grain wt } \\
\left(\mathrm{q} \mathrm{ha} \mathrm{h}^{-1}\right)\end{array}$ \\
\hline \multicolumn{9}{|c|}{ Main plots (Varieties)(V) } \\
\hline Peddasama & 144.75 & 5.80 & 21.26 & 1.01 & 26.01 & 19.83 & 85.41 & 8.96 \\
\hline OLM 203 & 148.99 & 8.68 & 27.91 & 1.00 & 28.72 & 21.01 & 102.05 & 10.02 \\
\hline SEm \pm & 1.30 & 0.12 & 0.60 & 0.01 & 0.58 & 0.46 & 1.19 & 0.26 \\
\hline$C D(p=0.05)$ & N.S & 0.73 & 3.68 & NS & NS & NS & 7.25 & NS \\
\hline \multicolumn{9}{|c|}{ Sub plots (Fertilizer levels) (T) } \\
\hline $\mathrm{T}_{1}$ & 129.58 & 3.92 & 17.85 & 0.97 & 20.83 & 17.13 & 55.92 & 4.93 \\
\hline $\mathrm{T}_{2}$ & 145.87 & 8.06 & 26.36 & 1.00 & 28.98 & 21.27 & 101.49 & 10.23 \\
\hline $\mathrm{T}_{3}$ & 151.47 & 7.45 & 24.71 & 1.01 & 27.16 & 19.51 & 91.52 & 9.78 \\
\hline $\mathrm{T}_{4}$ & 146.42 & 6.78 & 23.98 & 0.98 & 25.11 & 19.31 & 88.34 & 9.04 \\
\hline $\mathrm{T}_{5}$ & 149.42 & 8.66 & 26.50 & 0.99 & 30.10 & 21.73 & 101.32 & 10.95 \\
\hline $\mathrm{T}_{6}$ & 147.81 & 7.53 & 27.56 & 0.99 & 29.31 & 21.38 & 97.92 & 10.32 \\
\hline $\mathrm{T}_{7}$ & 149.44 & 6.68 & 23.91 & 1.00 & 27.21 & 19.48 & 88.81 & 9.46 \\
\hline $\mathrm{T}_{8}$ & 153.70 & 9.43 & 28.20 & 1.02 & 30.58 & 23.59 & 113.80 & 11.48 \\
\hline $\mathrm{T}_{9}$ & 151.31 & 7.74 & 25.96 & 0.98 & 28.81 & 21.36 & 110.75 & 11.03 \\
\hline $\mathrm{T}_{10}$ & 149.57 & 7.06 & 24.70 & 1.02 & 27.27 & 19.41 & 96.42 & 8.65 \\
\hline $\mathrm{T}_{11}$ & 141.08 & 6.33 & 20.76 & 0.99 & 25.64 & 19.49 & 84.77 & 7.72 \\
\hline SEm \pm & 2.68 & 0.40 & 0.97 & 0.02 & 1.10 & 1.00 & 5.32 & 0.50 \\
\hline $\mathrm{CD}(p=0.05)$ & 7.65 & 1.14 & 2.76 & NS & 3.15 & 2.85 & 15.20 & 1.44 \\
\hline $\begin{array}{l}\text { Interaction } \\
C D(p=0.05)\end{array}$ & NS & NS & NS & NS & NS & NS & NS & NS \\
\hline
\end{tabular}

$\mathrm{T}_{1}$ : 0\% RDF (Control); $\mathrm{T}_{2}: 100 \%$ RDF+FYM @ $5 \mathrm{t} \mathrm{ha}^{-1} ; \mathrm{T}_{3}:$ 75\% RDF+FYM @ $5 \mathrm{t} \mathrm{ha}^{-1}+$ Azospirillum @ $5 \mathrm{~kg} \mathrm{ha}^{-1}+\mathrm{PSB} @ 5 \mathrm{~kg} \mathrm{ha}{ }^{-1}$; $\mathrm{T}_{4}: 50 \%$ RDF+FYM @ $5 \mathrm{t} \mathrm{ha}^{-1}+$ Azospirillum @ $5 \mathrm{~kg} \mathrm{ha}^{-1}+$ PSB @ $5 \mathrm{~kg} \mathrm{ha}^{-1} ; \mathrm{T}_{5}: 100 \% \mathrm{RDF}+$ Vermicompost @ $2 \mathrm{t} \mathrm{ha}{ }^{-1} ; \mathrm{T}_{6}: 75 \%$ RDF+Vermicompost @ $2 \mathrm{t} \mathrm{ha}{ }^{-1}+$ Azospirillum @ $5 \mathrm{~kg} \mathrm{ha}^{-1}+\mathrm{PSB} @ 5 \mathrm{~kg} \mathrm{ha}^{-1} ; \mathrm{T}_{7}: 50 \% \mathrm{RDF}+$ Vermicompost @ $2 \mathrm{t}$ ha-1 + Azospirillum @ $5 \mathrm{~kg} \mathrm{ha}^{-1}+\mathrm{PSB} @ 5 \mathrm{~kg} \mathrm{ha}^{-1} ; \mathrm{T}_{8}: 100 \%$ RDF+Neem cake @ $1 \mathrm{t} \mathrm{ha}^{-1} ; \mathrm{T}_{9}: 75 \%$ RDF+Neem cake @ $1 \mathrm{t} \mathrm{ha}^{-1}+$ Azospirillum

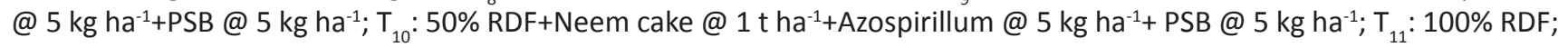

not combined with any of the organic manures. This is due to the increase in the growth parameters and increased uptake of available nutrients which caused increased photosynthetic rate resulting in higher yields. Similar results were reported by Leela Rani et al., 2015; Sandhya Rani, 2015. Significant difference in straw yields was recorded among both the varieties.

The effect of application of different types of organic manures viz., FYM, Vermicompost and Neem cake in conjunction with inorganic fertilizers was studied on physico-chemical properties (soil pH, E.C) (Table 2) and chemical properties (O.C, Available N, P, K and Cationic micronutrients) (Tables 3).

Soil $\mathrm{pH}$ has no significant influence on different levels of inorganic fertilizers in conjunction with organic manures. This might be due to the buffering action of organic matter added to the soil. Similar results were observed with FYM and NPK fertilizers (Alexandra et al., 2013; Santhy et al., 1999;
Ritamoni et al., 1999). The electrical conductivity of soil was not significantly influenced by different levels of inorganic fertilizers in conjunction with organic manures.

Organic carbon content was seen the highest in treatments 75\% RDF+Vermicompost @ $2 \mathrm{t} \mathrm{ha}^{-1}+$ Azospirillum 5 kg ha ${ }^{1}+P S B @ 5 \mathrm{~kg} \mathrm{ha}^{-1}$, but no significant difference was found between the treatments in which no organic manure is added in combination with inorganic fertilizers. Similar results were reported by Dasog et al., 1994; Mathur, 1997; Anwar et al., 2005.

The available $\mathrm{N}$ and $\mathrm{P}_{2} \mathrm{O}_{5}$ in soil were significantly influenced by three levels of fertilizers applied in conjunction with three types of organic manures and biofertilizers. Among all the treatments $100 \%$ RDF+Neem cake @ $1 \mathrm{t} \mathrm{ha}^{-1}$ showed the highest availability of $\mathrm{N}$, on par with $75 \% \mathrm{RDF}+$ Neem cake @ 1 t ha ${ }^{-1}+$ Azospirillum $5 \mathrm{~kg} \mathrm{ha}^{-1}+P S B @ 5 \mathrm{~kg} \mathrm{ha}^{-1}, 100 \% \mathrm{RDF}+\mathrm{FYM}$, @ $5 \mathrm{t} \mathrm{ha}^{-1} 100 \%$ RDF+Vermicompost @ $2 \mathrm{t} \mathrm{ha}^{-1}$ at the time of 
Table 2 :Effect of Integrated nutrient management on Physicochemical propertiesand soil OC

\begin{tabular}{|c|c|c|c|}
\hline & $\mathrm{pH}$ & E.C & O.C \% \\
\hline \multicolumn{4}{|c|}{ Main plots (Varieties)(V) } \\
\hline Peddasama & 6.44 & 0.09 & 0.46 \\
\hline OLM 203 & 6.43 & 0.09 & 0.47 \\
\hline SEm \pm & 0.03 & 0.003 & 0.004 \\
\hline $\mathrm{CD}(p=0.05)$ & NS & NS & NS \\
\hline \multicolumn{4}{|c|}{ Sub plots (Fertilizer levels) ( $T$ ) } \\
\hline $\mathrm{T}_{1}$ & 6.42 & 0.09 & 0.44 \\
\hline$T_{2}$ & 6.42 & 0.09 & 0.46 \\
\hline$T_{3}$ & 6.37 & 0.09 & 0.47 \\
\hline $\mathrm{T}_{4}$ & 6.39 & 0.09 & 0.45 \\
\hline$T_{5}$ & 6.37 & 0.09 & 0.48 \\
\hline $\mathrm{T}_{6}$ & 6.44 & 0.09 & 0.49 \\
\hline $\mathrm{T}_{7}$ & 6.51 & 0.10 & 0.48 \\
\hline $\mathrm{T}_{8}$ & 6.63 & 0.11 & 0.46 \\
\hline $\mathrm{T}_{9}$ & 6.41 & 0.09 & 0.48 \\
\hline $\mathrm{T}_{10}$ & 6.40 & 0.09 & 0.46 \\
\hline $\mathrm{T}_{11}$ & 6.45 & 0.08 & 0.46 \\
\hline SEm \pm & 0.05 & 0.01 & 0.02 \\
\hline $\mathrm{CD}(p=0.05)$ & N.S & NS & NS \\
\hline $\begin{array}{l}\text { Interaction CD } \\
(p=0.05)\end{array}$ & NS & NS & NS \\
\hline Initial & 6.5 & 0.27 & 0.46 \\
\hline
\end{tabular}

harvest of little millet crop. The control treatment recorded the lowest available nitrogen followed by 50\%RDF+FYM @ 5 t ha- ${ }^{-1}+$ Azospirillum $5 \mathrm{~kg} \mathrm{ha}^{-1}+P S B @ 5 \mathrm{~kg} \mathrm{ha}^{-1}$. Among all the treatments $100 \%$ RDF+Vermicompost @ $2 \mathrm{t} \mathrm{ha}^{-1}$ showed the highest available $\mathrm{P}_{2} \mathrm{O}_{5}$, on par with $75 \%$ RDF+Vermicompost @ 2 t ha ${ }^{-1}+$ Azospirillum $5 \mathrm{~kg} \mathrm{ha}^{-1}+P S B @ 5 \mathrm{~kg} \mathrm{ha}^{-1}, 100 \%$ RDF+Neem cake @ 1 t ha ${ }^{-1}$ and 100\% RDF+FYM @ 5 t ha ${ }^{-1}$. Among all the treatments $100 \%$ RDF+Vermicompost showed the highest available $\mathrm{K}_{2} \mathrm{O}$ but no significant difference was found between the treatments. Similar results were reported by Reddy and Reddy, 1998; Sandhya Rani and Reddy, 2014.

The available cationic micronutrients i.e. $\mathrm{Zn}$, Fe and $\mathrm{Mn}$ were significantly influenced by the application of different levels of fertilizers in combination with different types of manures. Available $\mathrm{Zn}$ and $\mathrm{Fe}$ in the soil was found highest in the treatment $100 \%$ RDF+Neem cake and on par with all the other treatments except control plot. Available $\mathrm{Cu}$ and $\mathrm{Mn}$ were found highest in the treatment with $100 \%$ RDF+Vermicompost @ $2 \mathrm{t} \mathrm{ha}^{-1}$ which is due to mineralization of soil organic matter. Results reveal that the uptake of both macro and micronutrients by little millet was significantly influenced by the integrated use
Table 3 :Effect of Integrated nutrient management on soil available macronutrients and micronutrients of Little Millet

\begin{tabular}{|c|c|c|c|c|c|c|c|}
\hline & AN & AP & AK & $\mathrm{AZ}$ & $\mathrm{AF}$ & $A C$ & AM \\
\hline \multicolumn{8}{|c|}{ Main plots (VARIETIES)(V) } \\
\hline $\begin{array}{l}\text { Ped- } \\
\text { dasa- } \\
\text { ma }\end{array}$ & 217 & 73 & 262 & 1.30 & 12.85 & 2.14 & 7.95 \\
\hline $\begin{array}{l}\text { OLM } \\
203\end{array}$ & 222 & 79 & 268 & 1.34 & 13.72 & 2.06 & 7.62 \\
\hline SEm \pm & 7.52 & 1.124 & 2.848 & 0.021 & 0.222 & 0.033 & 0.011 \\
\hline$C D^{*}$ & NS & NS & NS & NS & 1.35 & NS & NS \\
\hline \multicolumn{8}{|c|}{ Sub plots (Fertilizer levels) (T) } \\
\hline $\mathrm{T}_{1}$ & 172 & 57 & 231 & 1.03 & 12.06 & 1.69 & 6.65 \\
\hline$T_{2}$ & 228 & 78 & 271 & 1.35 & 13.82 & 2.29 & 8.29 \\
\hline $\mathrm{T}_{3}$ & 221 & 74 & 262 & 1.30 & 13.24 & 2.28 & 8.12 \\
\hline $\mathrm{T}_{4}$ & 204 & 72 & 259 & 1.27 & 13.38 & 2.12 & 7.63 \\
\hline $\mathrm{T}_{5}$ & 236 & 87 & 281 & 1.60 & 13.98 & 2.39 & 8.51 \\
\hline $\mathrm{T}_{6}$ & 223 & 82 & 273 & 1.32 & 13.67 & 2.13 & 8.19 \\
\hline $\mathrm{T}_{7}$ & 212 & 75 & 260 & 1.28 & 13.26 & 2.04 & 7.54 \\
\hline $\mathrm{T}_{8}$ & 249 & 80 & 277 & 1.49 & 14.07 & 2.31 & 8.08 \\
\hline $\mathrm{T}_{9}$ & 238 & 77 & 269 & 1.35 & 13.29 & 1.99 & 7.71 \\
\hline $\mathrm{T}_{10}$ & 211 & 74 & 259 & 1.24 & 12.97 & 2.01 & $7 . .28$ \\
\hline $\mathrm{T}_{11}$ & 221 & 76 & 272 & 1.30 & 12.36 & 1.86 & 7.64 \\
\hline SEm \pm & 8.02 & 3.28 & 10.17 & 0.16 & 0.58 & 0.15 & 0.27 \\
\hline $\mathrm{CD}^{*}$ & 22.92 & 9.39 & NS & 0.45 & 1.67 & NS & 0.76 \\
\hline $\mathrm{I}_{\mathrm{CD}}^{*}$ & NS & NS & NS & NS & NS & NS & NS \\
\hline ISTV & 254.5 & 72.8 & 317 & 1.20 & 12.36 & 2.05 & 8.42 \\
\hline
\end{tabular}

AN: Available N (kg ha-1); AP: Available $\mathrm{P}_{2} \mathrm{O}_{5}\left(\mathrm{~kg} \mathrm{ha}^{-1}\right)$; $\mathrm{AK}$ : Available $\mathrm{K}_{2} \mathrm{O}\left(\mathrm{kg} \mathrm{ha}^{-1}\right)$; AZ: Avail Zn (ppm); AF: Avail Fe (ppm); AC: Avail Cu (ppm); AM: Avail Mn (ppm); CD*: CD ( $p=0.05)$; I $C^{*}$ : Interaction CD ( $\left.p=0.05\right)$; ISTV: Initial soil test values

of different levels of fertilizers in combination with different types of organic manures (FYM, Vermicompost and Neem cake) and biofertilizers. Among all the treatments nitrogen uptake was highest in the treatment $100 \%$ RDF+Neem cake which is on par with the treatment $100 \% \mathrm{RDF}+$ Vermicompost @ $2 \mathrm{t} \mathrm{ha}^{-1}$ (Table 4). The increased uptake of nitrogen might be due to the increased amount of dry matter production due to balanced release of these nutrients into soil upon manure decomposition, which results in vigorous growth and uptake of nutrients. Similar results were reported by Ramakrishna and Bhuvaneswari, 2014; Chung et al., 2000.

The uptake of Phosphorus was found highest in the treatment 100\% RDF+Neem Cake @ $1 \mathrm{t} \mathrm{ha}^{-1}\left(\mathrm{~T}_{8}\right)$ when compared to the control and $100 \%$ RDF. Further it is found on par with the treatments 75\% RDF+Neem cake @ $1 \mathrm{t} \mathrm{ha}^{-1}+$ Azospirillum 
Table 4: Effect of Integrated nutrient management on nutrient uptake of little millet

\begin{tabular}{|c|c|c|c|c|c|}
\hline & NU & PU & KU & $\mathrm{ZU}$ & $\mathrm{FU}$ \\
\hline \multicolumn{6}{|c|}{ Main plots (Varieties)(V) } \\
\hline Peddasama & 57.29 & 23.13 & 32.90 & 169.4 & 654.39 \\
\hline OLM 203 & 59.50 & 31.16 & 37.22 & 198.3 & 757.43 \\
\hline SEm \pm & 1.21 & 0.85 & 2.58 & 3.1 & 22.7 \\
\hline$C D(p=0.05)$ & NS & 5.27 & NS & 18.30 & NS \\
\hline \multicolumn{6}{|c|}{ Sub plots (Fertilizer levels) (T) } \\
\hline $\mathrm{T}_{1}$ & 30.39 & 12.72 & 17.97 & 112.5 & 478.1 \\
\hline $\mathrm{T}_{2}$ & 65.70 & 35.75 & 43.67 & 203.5 & 808.3 \\
\hline $\mathrm{T}_{3}$ & 56.22 & 28.87 & 36.62 & 179.2 & 632.9 \\
\hline $\mathrm{T}_{4}$ & 48.75 & 23.14 & 30.32 & 158.2 & 554.9 \\
\hline $\mathrm{T}_{5}$ & 68.02 & 32.24 & 41.03 & 240.1 & 944.8 \\
\hline $\mathrm{T}_{6}$ & 61.72 & 27.36 & 36.01 & 193.7 & 812.6 \\
\hline $\mathrm{T}_{7}$ & 50.61 & 21.09 & 28.37 & 153.1 & 526.6 \\
\hline $\mathrm{T}_{8}$ & 81.87 & 38.40 & 47.98 & 236.5 & 923.5 \\
\hline $\mathrm{T}_{9}$ & 70.52 & 33.41 & 43.56 & 223.8 & 831.9 \\
\hline $\mathrm{T}_{10}$ & 57.67 & 24.41 & 32.33 & 171.0 & 611.6 \\
\hline $\mathrm{T}_{11}$ & 50.89 & 21.18 & 27.81 & 150.5 & 639.9 \\
\hline SEm \pm & 5.11 & 1.91 & 2.58 & 13.5 & 61.7 \\
\hline $\mathrm{CD}(p=0.05)$ & 14.62 & 5.16 & 7.36 & 38.5 & 176.3 \\
\hline $\begin{array}{l}\text { Interaction } \\
\mathrm{CD}(p=0.05)\end{array}$ & NS & NS & NS & NS & NS \\
\hline
\end{tabular}

NU: N uptake (kg ha-1 $)$; PU: P uptake $\left(\mathrm{kg} \mathrm{ha}^{-1}\right)$; KU: K uptake ( $\left.\mathrm{kg} \mathrm{ha}^{-1}\right)$; ZU: Zn uptake (g ha ${ }^{-1}$ ); FU: Fe uptake ( $\mathrm{g} \mathrm{ha}^{-1}$ )

$5 \mathrm{~kg} \mathrm{ha}^{-1}+P S B @ 5 \mathrm{~kg} \mathrm{ha}^{-1}\left(\mathrm{~T}_{9}\right), 100 \%$ RDF+FYM @ $5 \mathrm{t} \mathrm{ha}^{-1}$ $\left(\mathrm{T}_{2}\right)$. Moreover the uptake of phosphorus was found significantly highest in the variety OLM $203(31.16 \mathrm{~kg} \mathrm{ha}$ $\left.{ }^{1}\right)$ compared to peddasama $\left(23.13 \mathrm{~kg} \mathrm{ha}^{-1}\right)$. The increased uptake of phosphorus by both the varieties of little millet may be attributed to the increased availability of $P$ due to solubilizing effect of organic acids which are produced from the decomposing organic manures. Further organic manures also reduce the fixation of phosphorus and increase the available phosphorus concentration in soil solution for absorption resulting in increased uptake of phosphorus by little millet. Similar results were reported by Vasanthi and Kumarswamy, 2000. The uptake of potassium was found highest in the treatment $100 \%$ RDF+Neem cake @ 1 t ha ${ }^{-1}$ which was on par with the treatments 100\% RDF+FYM @ $5 \mathrm{t} \mathrm{ha}^{-1}, 100 \%$ RDF+Vermicompost @ $2 \mathrm{t} \mathrm{ha}^{-1}$ and 75\% RDF+Neem cake @ $1 \mathrm{t} \mathrm{ha}^{-1}+$ Azospirillum $5 \mathrm{~kg} \mathrm{ha}^{-1}+P S B @ 5 \mathrm{~kg} \mathrm{ha}^{-1}$. The highest potassium uptake might be because potassium is likely to be maintained in exchangeable form in soils treated with organic manures due to high exchange capacity of organic colloids formed during decomposition of organic manure, which in turn restricted the $\mathrm{K}^{+}$ions getting fixed by inorganic clay particles in soil. The uptake of cationic micronutrients like $\mathrm{Zn}$ and Fe by both varieties of little millet crop was found to be highest in the treatment $100 \%$ RDF+Vermicompost @ $2 \mathrm{tha}^{-1}\left(\mathrm{~T}_{5}\right)$, which was found on par with the treatments $75 \%$ RDF+Neem cake@ $1 \mathrm{t} \mathrm{ha}{ }^{-1}+$ Azospirillum $5 \mathrm{~kg} \mathrm{ha}^{-1}+P S B @ 5$ $\mathrm{kg} \mathrm{ha}^{-1}\left(\mathrm{~T}_{9}\right), 100 \%$ RDF+Vermicompost @ $2 \mathrm{t} \mathrm{ha}^{-1}\left(\mathrm{~T}_{4}\right), 75 \%$ RDF+Vermicompost @ 2 t ha- ${ }^{-1}+$ Azospirillum $5 \mathrm{~kg} \mathrm{ha}^{-1}+P S B @$ $5 \mathrm{~kg} \mathrm{ha}^{-1}\left(\mathrm{~T}_{4}\right)$ and $100 \%$ RDF+FYM @ $5 \mathrm{t} \mathrm{ha}^{-1}\left(\mathrm{~T}_{2}\right)$ and lowest was recorded by control followed by $100 \%$ RDF (Table 4.). This may be due to the faster decomposition of organic manures due to lowering of C:N ratio. Similar results were recorded by Tewari et al., 1993.

Different integrated nutrient management practices significantly influenced both the net returns and benefit cost ratioin little millet (Table 5). Gross returns was found highest in the treatment with 100\% RDF+Neem cake @ $1 \mathrm{t} \mathrm{ha}^{-1}$ in both Peddasama and OLM 203 varieties ( $₹ 27,524$ ha $^{-1}$ and ₹

Table 5: Economics of integrated nutrient management of little millet

\begin{tabular}{|c|c|c|c|c|c|c|}
\hline & GY & SY & GR & CC & NR & $\mathrm{B}: \mathrm{C}$ \\
\hline V1T1 & 0.46 & 4.77 & 11637 & 7000 & 4637 & 1.66 \\
\hline V1T2 & 0.92 & 9.32 & 22967 & 13200 & 9767 & 1.74 \\
\hline V1T3 & 0.9 & 8.23 & 22170 & 13750 & 8420 & 1.61 \\
\hline V1T4 & 0.87 & 7.63 & 21116 & 13300 & 7816 & 1.59 \\
\hline V1T5 & 1.04 & 9.6 & 25600 & 22200 & 3400 & 1.15 \\
\hline V1T6 & 1.00 & 9.3 & 24616 & 22750 & 1866 & 1.08 \\
\hline V1T7 & 0.95 & 7.65 & 22777 & 22300 & 477 & 1.02 \\
\hline V1T8 & 1.11 & 10.82 & 27524 & 18700 & 8824 & 1.47 \\
\hline V1T9 & 1.07 & 10.62 & 26753 & 19250 & 7503 & 1.39 \\
\hline V1T10 & 0.83 & 8.8 & 21061 & 18800 & 2261 & 1.12 \\
\hline V1T11 & 0.76 & 7.23 & 18740 & 9200 & 9540 & 2.04 \\
\hline V2T1 & 0.52 & 6.42 & 13673 & 7000 & 6673 & 1.95 \\
\hline $\mathrm{V} 2 \mathrm{~T} 2$ & 1.13 & 10.98 & 28107 & 13200 & 14907 & 2.13 \\
\hline V2T3 & 1.05 & 10.07 & 26085 & 13750 & 12335 & 1.90 \\
\hline V2T4 & 0.94 & 10.04 & 23896 & 13300 & 10596 & 1.80 \\
\hline V2T5 & 1.15 & 10.67 & 28349 & 22200 & 6149 & 1.28 \\
\hline V2T6 & 1.07 & 10.29 & 26461 & 22750 & 3711 & 1.16 \\
\hline V2T7 & 0.98 & 10.12 & 24729 & 22300 & 2429 & 1.11 \\
\hline V2T8 & 1.19 & 11.94 & 29768 & 18700 & 11068 & 1.59 \\
\hline V2T9 & 1.13 & 11.53 & 28429 & 19250 & 9179 & 1.48 \\
\hline V2T10 & 0.9 & 10.49 & 23199 & 18800 & 4399 & 1.23 \\
\hline V2T11 & 0.79 & 9.72 & 20618 & 9200 & 11418 & 2.24 \\
\hline
\end{tabular}

GY: Grain yield (t ha- $\left.{ }^{-1}\right)$ : SY: Straw yield (t ha-1); GR: Gross returns ( $\left(\mathrm{ha}^{-1}\right)$; CC: Cost of cultivation ( $₹$ ha-1); NR: Net returns (₹ ha-1); 
29,768 ha-1 $^{-1}$ respectively). Whereas the net returns was found highest in the treatment with 100\% RDF+FYM @ 5 t ha ${ }^{-1}$ in both Peddasama and OLM 203 varieties ( $₹ 9767$ ha $^{-1}$ and ₹ 14907 $\mathrm{ha}^{-1}$ ) as the cost of cultivation was less in FYM treated plots compared to Neem cake. But the benefit cost ratio was found highest in $100 \%$ RDF treated plots in both Peddasama and OLM 203 varieties ( 2.04 and 2.24 respectively) closely followed by 100\% RDF+FYM @ 5 t ha-1 (1.75 and 2.13 respectively).

\section{Conclusion}

100\% RDF+Neemcake @ $1 \mathrm{t} \mathrm{ha}^{-1}$ has given the highest yields compared to FYM and Vermicompost; highest benefit cost ratio was found in $100 \%$ RDF plot. keeping in view of the soil health, $100 \%$ RDF+FYM treated plot has given next best benefit:cost ratio which is considered to be the best treatment compared to all the other organic manures.

\section{References}

Adani, F., Genevini, P., Ricca, G., Tambone, F., Montoneri, E., 2007. Modification of soil humic matter after 4 years of compost application. Waste Management 27, 319-324.

Anwar, M., Patra, D.D., Chand, S., Kumar, A., Naqvi, A., Khanuja, S.P.S., 2005. Effect of Organic manures and Inorganic Fertilizers on growth, Herb and Oil yield, Nutrient Accumulation and oil quality of French Basil. Communication in Soil Science and Plant Analysis 36(13-14), 1737-1746.

Chung, R.S., Wang, C.H., Wang, C.W., Wang, Y.P., 2000. Influence of organic matter and inorganic fertilizer on the growth and nitrogen accumulation of corn plants. Journal of Plant Nutrition 23(3), 297-311.

Dasog, G.S., Basavaraja, P.K., Vijasekhar, R., 1994. Effect of FYM and fertilizer application on sorghum yield and soil fertility in an irrigated vertisol. National Seminar on Development in soil science 1994. Indian society of soil science, Division of Soil Science and Agricultural Chemistry, IARI, New Delhi 727-728.

Reddy, B., Reddy, S., 1998. Effect of organic manures and nitrogen levels on soil available nutrient status in maize soyabean cropping system. Journal of Indian society of soil science 46, 474-476.

Hati, K.M., Mandal, K.G., Misra, A.K., Ghosh, P.K., Bandhyopadhyay, K.K., 2006. Effect of Inorganic fertilizer and farmyard manure on soil physical properties, root distribution and water use efficiency of soybean in vertisols of Central India. Bioresource Technology 97(16), 2182-2188.

Kowaljow, E., Mazzarino, M.J., 2007. Soil restoration in semiarid Patagonia: Chemical and biological response to different compost quality. Soil Biology and Biochemistry 39, 1580-1588.

Kumar, A., Tripathi, H.P., Yadav, D.S., 2007. Correcting nutrients for sustainable crop production. Indian Journal of Fertilizers 2, 37-44.
Larney, F.J., Hao, X., 2007. A review of composting as a management alternative for beef cattle feedlot manure in southern Alberta, Canada. Bioresource Technology 98, 3221-3227.

Leela Rani, P., Balaswamy, K., Ramachandra Rao., A., Masthan, S.C., 2015. Evaluation of Integrated Nutrient Management practices on Growth, Yield and Economics of Green chilli cv Pusa Jwala (Capsicum annum L.). International Journal of Bioresource and Stress Management 6(1), 76-80.

Mathur, G.M., 1997. Effect on long term application of fertilizers and manures on soil properties and yield under cotton -wheat rotation in North-west Rajasthan. Journal of Indian Society of Soil Science 45(2), 288-292.

Pedra, F., Polo, A., Ribero, A., Domingues, H., 2007. Effects of municipal solid waste compost and sewage sludge on mineralization of soil organic matter. Soil Biology and Biochemistry 39, 1375-1382.

Pullicinoa, S.D., Massaccesia, L., Dixnob, L., Bolb, R., Gigliottia, G., 2009. Organic matter dynamics in a compostamended anthropogenic land fill capping-soil. European Journal of Soil Science 61, 35-47.

Ramakrishnan, K., Bhuvaneswari, G., 2014. Effect of inoculation of am fungi and beneficialmicroorganisms on growth and nutrient uptake of Eleusine coracana (L.) Gaertn. (Finger millet). International Letters of Natural Sciences 13, 59-69.

Reeves, D.W., 1997. The role of soil organic matter in maintaining soil quality in continuous cropping systems. Soil Tillage Research 10(1), 31-36.

Ritamoni, B., Haridev, T., Talukdar, N.C., Baruah, R., Talukdar, H., 1999. Soil chemical properties as influenced by the application of fertilizers and farmyard manure. International journal of Tropical Agriculture 17(1-4), 153-158.

Sandhya Rani, Y., 2015. Effect of combined use of organic and inorganic nutrient sources on plant nutrient content and uptake in Turmeric+Maize intercropping system. Progressive Research-An international Journal 10(2), 103-105.

Sandhya Rani, Y., Reddy, S., 2014. Cumulative effect of Organic Manures on soil health in Turmeric+ Maize intercropping system. Research Journal of Agricultural Sciences 5(6), 125-127.

Santhy, P., Velusomy, M., Murugappan, S., Selvi, V., 1999. Effect of inorganic fertilizers and fertilizer manure combination on soil physico-chemical properties and dynamics of microbial biomass in an Inceptisol. Journal of the Indian society of soil science 47(3), 479-482.

Sebastia, J., Labanowski, J., Lamy, 2007. Changes in soil organic matter chemical properties after organic amendments. Chemosphere 68, 1245-1253.

Schulz, H., Glaser, B., 2012. Effects of Biochar compared to organic and inorganic fertilizers on soil quality and plant 
growth in a green house experiment. Journal of Plant Nutrition and Soil Science 175(3), 410-422.

Singh, R., Agarwal, S.K., 2001. Analysis of growth and productivity of wheat (Triticum aestivum L.) in relation to levels of FYM and nitrogen. Indian Journal of Plant Physiology 6, 279-283.

Tewari, L., Johri, B.N., Tandon, S.M., 1993. Host genotype dependency and growth enhancing ability of VAmycorrhizal fungi for Eleusine coracana (finger millet). World Journal ofMicrobiology and Biotechnology9, 191-195.

Vasanthi, D., Kumaraswamy, K., 2000. Effects of ManureFertilizer schedules on the yield and uptake of nutrients by cereal fodder crops and on soil fertility. Journal of the Indian Society of Soil Science 48(3), 510-515.
Weber, J., Karczewska, A., Drozd, J., Licznar, M., Licznar, S., Jamroz, E., 2007. Agricultural and ecological aspects of a sandy soil as affected by the application of municipal solid waste composts. Soil Biology and Biochemistry39, 1294-1302.

Zeidan, M.S., 2007. Effect of organic manures and phosphorus fertilizers on growth, yield and quality of lentil plants in sandy soils. Research Journal of Agricultural and Biological Sciences 3(6), 748-752.

Zhong, W.H., Cai, Z.C., 2007. Long-term effects of inorganic fertilizers on microbial biomass and community functional diversity in a paddy soil derived from quaternary red clay. Applied Soil Ecology 36(2-3), 84-91. 